\title{
Decision Making System Internet Addiction in Children Aged 7-17 Year Use Forward Chaining Method (Case Study : Terik Village - Krian, Sidoarjo)
}

\section{Sistem Pengambil Keputusan Kecanduan Internet Pada Anak Usia 7 - 17 Tahun Menggunakan Metode Forward Chaining (Studi Kasus : Desa Terik - Krian, Sidoarjo)}

\author{
Elfi Ratna Furi ${ }^{1}$, Ika Ratna Indra Astutik ${ }^{2}$ \\ [elfiratna11s1@gmail.com ${ }^{1}$, ikaratna@umsida.ac.id²] \\ Program Studi Informatika, Fakultas Sains dan teknologi, Universitas Muhammadiyah Sidoarjo
}

\begin{abstract}
Based on a survey conducted by the APJII (Indonesian Internet Service Providers Association) team in 2018 with a percentage of more than $64.8 \%$ using the internet. The highest percentage is at the age of 7-19 years, which is $91 \%$, this shows that the number of internet users is getting higher every year. This study aims to help treat children who are addicted to the Internet and as advice or a reference for making decisions on how to deal with people who are addicted to the Internet. The method used was to collect data on the distribution of questionnaires or questions that were carried out directly on children aged 7-17 years in the blistering village. The results of external application testing with Likert scale calculations get a percentage result of $78.36 \%$ (very useful).
\end{abstract}

Keywords - internet addiction; decision making system; parents; early childhood; empathy

\begin{abstract}
Abstrak. Berdasarkan survey yang dilaksanakan tim APJII (Asosiasi Penyedia Jasa Internet Indonesia) tahun 2018 dengan presentase lebih dari 64,8\% telah menggunakan internet. Presentase tertinggi ada pada usia 7-19 tahun yaitu sebesar $91 \%$ hal ini menunjukkan bahwa angka pengguna internet semakin tingi setiap tahunnya. Penelitian ini bertujuan untuk membantu menangani anak yang sudah kecanduan internet dan sebagai saran atau rujukan untuk pembuatan keputusan bagaimana menangani orang yang mengalami kecanduan Internet. Metode yang digunakan dengan mengumpulkan data pembagian angket atau pertanyaan yang dilakukan langsung pada anak usia 7-17 tahun di desa terik - krian. Hasil pengujian aplikasi secara eksternal dengan perhitungan skala likert mendapatkan hasil prosentase sebesar $78.36 \%$ (sangat bermanfaat).
\end{abstract}

Kata kunci - kecanduan internet; sistem pengambil keputusan; orangtua; anak usia dini; empati

\section{PENDAHULUAN}

Kecanduan internet atau Internet Addictionmerupakan fenomena yang mencemaskan dan sangat menarik untuk diperhatikan. Internet telah membuat remaja kecanduan, karena menawarkan berbagai macam informasi, permainan, dan hiburan.Hal ini ditandai dengan rasa senang dengan internet, durasi penggunaan internet terus meningkat dan menjadi cemas dan bosan apabila harus melalui beberapa hari tanpa internet. [1] Penderita gangguan kepribadian bisa dikenali dengan beberapa ciri yaitu berperilaku aneh, mengurung diri atau menghindari interaksi sosial, sulit menjalin hubungan dekat dengan orang lain, kesulitan mengendalikan pikiran dan sering berprasangka buruk.[2] Berdasarkan survei yang sudah dilaksanakanoleh timAPJII atau (Asosiasi Penyelenggara Jasa Internet Indonesia) pada tahun 2018 sudah terdapat sebanyak 171,17 juta jiwa dari total 264,16 juta jiwa penduduk Indonesia, itu menunjukkan bahwa sudah ada lebih dari $64,8 \%$ yang sudah menggunakan internet di Indonesia pada tahun tersebut. Mulai dari usia 5 tahun sampai dengan usia65 tahun saat ini sudahmengenal apa itu internet, persentase tertinggi yang mendominasi usia 7 - 19 tahun sekitar 91\%. Hal tersebut menandakan bahwa angka pengguna internet semakin tinggi setiap tahunnya.[3]

Persentase akses konten yang sering dilakukan di Indonesia sendiri mulai dari Chatting $89 \%$, Sosial Media $87 \%$, Search Engine 74,84\%, Lihat Video 69,64\%, Mendownload Video 70,23\%, Dll. Data tersebut mengacu padasurvey APJII (Asosiasi Penyelenggara Jasa Internet Indonesia) pada tahun 2018, Kesimpulan yang bisa didapatkan yaitu semua orang di Indonesia sudah terhubung dengan jaringan internet mulai dari penggunaan Search Engine dan Melihat/Mendownload Video yang mempunyai konten negative. [4]

Maka berdasarkan kondisi pandemik seperti saat ini dan permasalahan diatas penulis memiliki ide judul "Sistem Pengambil Keputusan Kecanduan internet pada anak usia 7 -17 Tahun Menggunakan Metode Forward Chaining”.

Dalam pembangunan sistem ini penulis berharap para praktisi bisa belajar untuk melakukan pendekatanpendekatan dalam melakukan penanganan klien yang sedang dalam kondisi tersebut. 


\section{METODE}

\section{A. Teknik pengumpulan data}

Pada penelitian ini diperlukan data dan informasi seperti pengisian kuisioner/angket yang akan disebarkan kepada Anak-anak mulai dari Usia 7 sampai 15 Tahun. Agar data dan informasi tersebut bisa terkumpul, penulis menggunakan metode pengumpulan data kuisioner.

\section{B. Kuisioner atau Angket}

Yaitu metode pengumpulan data dengan melakukan pembagian angket atau pertanyaan yang sudah dipersiapkan sebelumnya. Kuisioner ini dilakukan langsung pada Anak-anak Usia 7 - 17 Tahun di Ds.Terik Kelurahan Terik - Kec. Krian, Sidoarjo secara langsung.

\section{Forward Chaining}

Forward Chaining adalah suatu strategi pengambilan keputusan yang dimulai dari bagian premis (fakta) menuju konklusi (kesimpulan akhir), Forward Chaining merupakan grup dari multiple inferensi yang melakukan pencarian dari suatu masalah kepada solusinya. Jika klausa premis sesuai dengan situasi (bernilai TRUE), maka proses akan meng-assert konklusi. Pelacakan ke depan mencari fakta yang sesuai dari bagian IF dari aturan IFTHEN. [5]

Forward Chaining digunakan apabila :

1. Banyak aturan berbeda yang dapat memberikan kesimpulan yang sama.

2. Banyak cara untuk mendapatkan sedikit konklusi.

3. Benar-benar sudah mendapatkan berbagai fakta dan ingin mendapatkan konklusi dari fakta-fakta tersebut.

\section{Metode Forward Chaining}

Dimulai dari sejumlah fakta-fakta yang telah diketahui untuk mendapatkan suatu fakta baru dengan memakai rule-rule yang memiliki ide dasar yang cocok dengan fakta dan terus dilanjutkan sampai mendapatkan suatu kesimpulan akhir. Adapun alur proses metode Forward Chaining ditunjukkan pada pohon keputusan dibawah ini.

\section{E. POHON KEPUTUSAN}

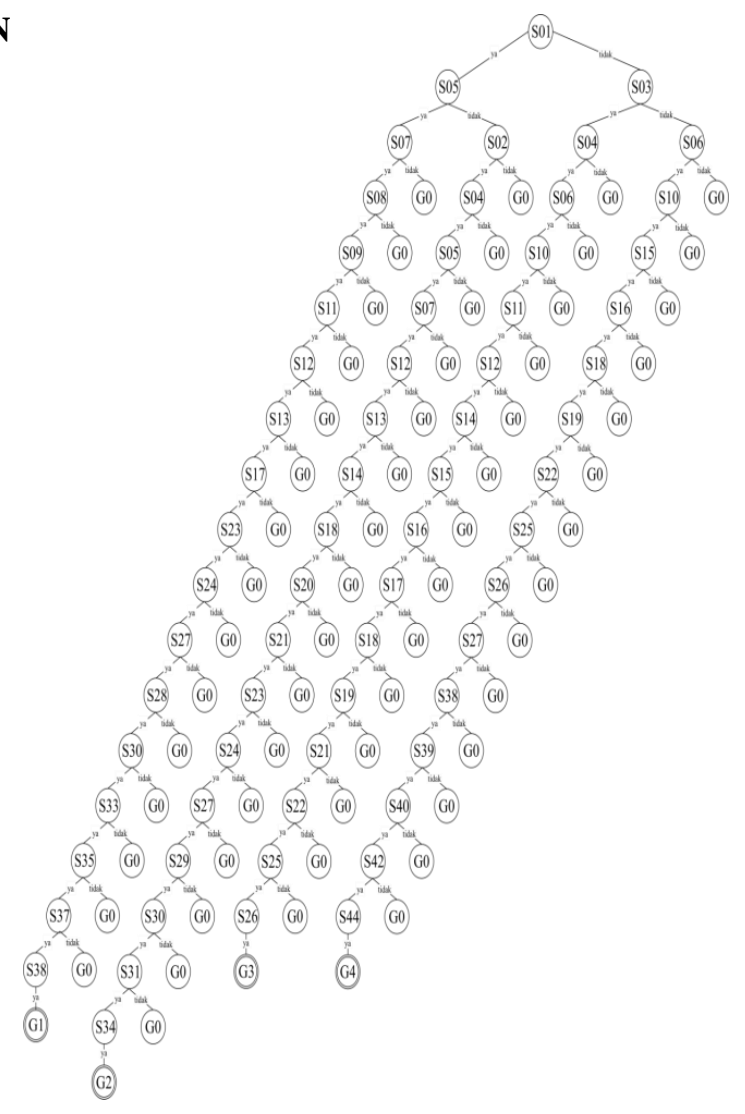


Procedia of Engineering and Life Science Vol. 1. No. 2 Juni 2021

Seminar Nasional \& Call Paper Fakultas Sains dan Teknologi (SENASAINS 2nd)

Universitas Muhammadiyah Sidoarjo

\section{F. Perancangan Sistem}

Flow chart

Flowchart adalah sebuah gambaran dalam bentuk diagram alir dari algoritma-algoritma dalam suatu program, yang menyatakan alur program tersebut. [6]

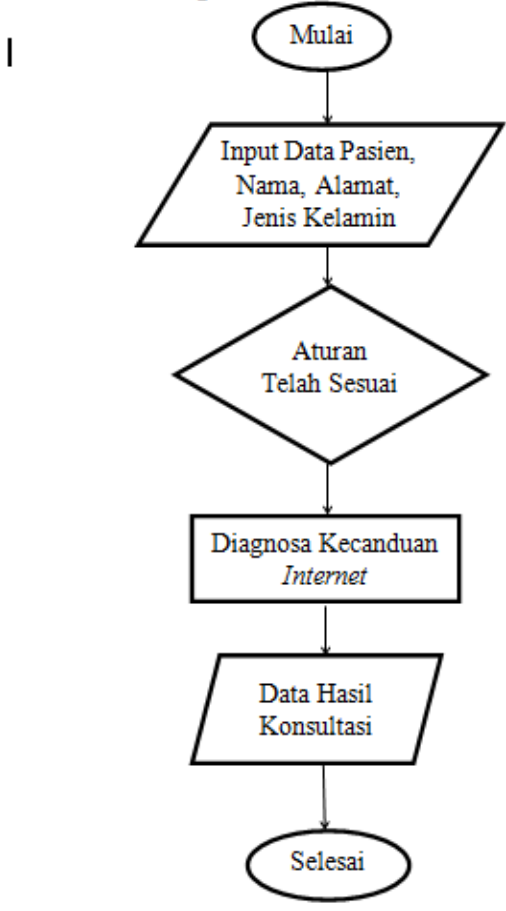

Gambar 1. Flowchart

\section{Data Flow Diagram}

Data Flow Diagram (DFD) adalah diagram alir yang dipresentasikan dalam bentuk lambang - lambang tertentu yang menunjukkan aliran data, proses, tempat, penyimpanan data, dan entitas eksternal.

\section{Diagram Konteks}

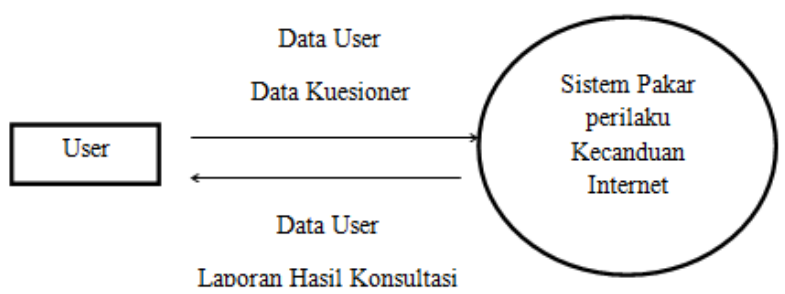

Gambar 2. Diagram Konteks

Pada Diagram Konteks user mendapatkan sekilas info mengenai apa itu Kecanduan Internet, dan bahaya Kecanduan Internet yang ada pada sistem dan dapat langsung mengakses sistem pakar tersebut dengan masuk ke menu konsultasi dan menginputkan data diri sebelum proses konsultasi berjalan. Dan laporan hasil analisa akan diterima oleh user. 
Procedia of Engineering and Life Science Vol. 1. No. 2 Juni 2021

Seminar Nasional \& Call Paper Fakultas Sains dan Teknologi (SENASAINS 2nd)

Universitas Muhammadiyah Sidoarjo

Data Flow Diagram Level 1

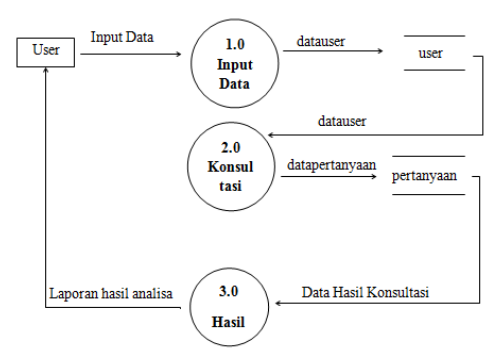

Gambar 3. DFD Level 1

Pada Data Flow Diagram level 1, proses pengolahan data digunakan untuk menjelaskan kegiatan arus data dalam sistem pakar, dalam diagram ini user melakukan input data diri kemudian melakukan proses konsultasi dan akan mendapatkan hasil dari konsultasi tersebut dan user langsung mendapatkan hasil dari analisa yang sudah dilakukan.

\section{Relasi Antar Tabel}

Entity Relationship diagram (ERD) merupakan teknik yang digunakan untuk memodelkan kebutuhan data dari suatu organisasi, biasanya oleh System Analys dalam tahap analisis persyaratan proyek pengembangan system. [7]

Berikut ini adalah gambaran dari tabel-tabel atau entitas yang diperlukan dalam membuat sebuah database Sistem Pengambil Keputusan Kecanduan Internet Pada Anak Usia 7 - 17 Tahun Menggunakan Metode Forward Chaining.

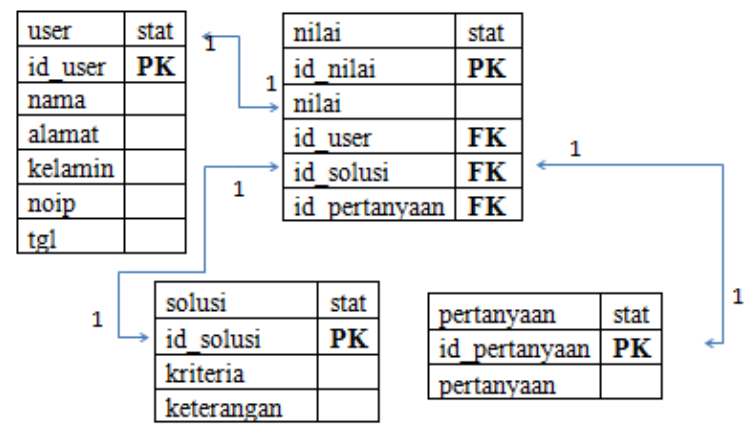

Gambar 4. Relasi Antar Tabel

\section{A. Hasil penelitian}

\section{HASIL DAN PEMBAHASAN}

Hasil penelitian ini adalah Sistem Pengambil Keputusan Kecanduan Internet Pada Anak usia 7-17 Tahun Menggunakan Metode Forwad Chaining.

\section{B. Pengujian Aplikasi}

Tabel 1. Tabel Kuisioner Pengujian

\begin{tabular}{cllll}
\hline No & \multicolumn{1}{c}{ Item Kuisioner } & 1 & 2 & 3 \\
\hline 1 & Apakah tampilan Aplikasi ini menarik? & 2 & 68 & 33 \\
\hline 2 & Apakah Aplikasi tersebut mudah dipahami? & 3 & 63 & 37 \\
\hline 3 & Apakah Aplikasi ini membantu anda? & 10 & 63 & 33 \\
\hline 4 & Apakah fitur - fitur pada Aplikasi ini mudah dimengerti? & 1 & 66 & 38 \\
\hline 5 & Apakah Aplikasi ini Efektif? & 7 & 62 & 37 \\
\hline 6 & Apakah Aplikasi ini bermanfaat? & 7 & 66 & 33 \\
\hline
\end{tabular}


Procedia of Engineering and Life Science Vol. 1. No. 2 Juni 2021

Seminar Nasional \& Call Paper Fakultas Sains dan Teknologi (SENASAINS 2nd)

Universitas Muhammadiyah Sidoarjo

Berdasarkan kuisioner pengujian dari responden yang terkait dengan sistem, maka diperoleh skor 3 dengan jumlah poin 211, Skor 2 dengan jumlah poin 388, dan skor 1 dengan jumlah poin 30. Sehingga dapat disimpulan bahwa hasil penelitian dapat berjalan dengan baik sesuai dengan pengujian pengguna.

\section{Pembahasan}

Pop Up HalamanAwal

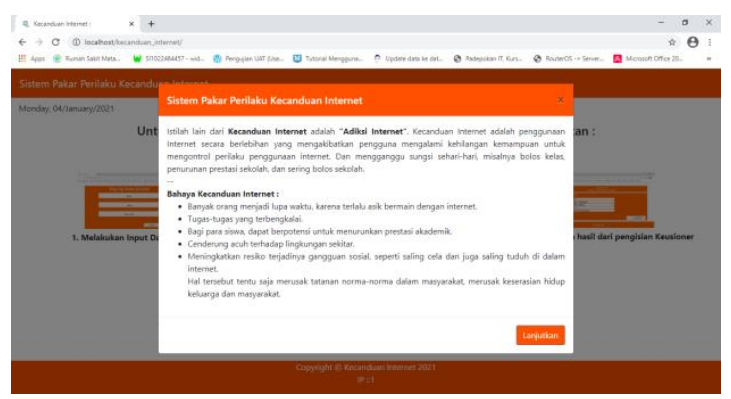

Gambar 5. Pop Up Halaman Awal

User/Pengguna ketika melakukan Akses ke web pertama kali yang keluar adalah halaman Pop Up yang berisikan artikel tentang apa itu Kecanduan Internet dan Bahaya Kecanduan Internet.Dan disediakan tombol "Lanjutkan" untuk melakukan Close Pop Up.

\section{Halaman Home}

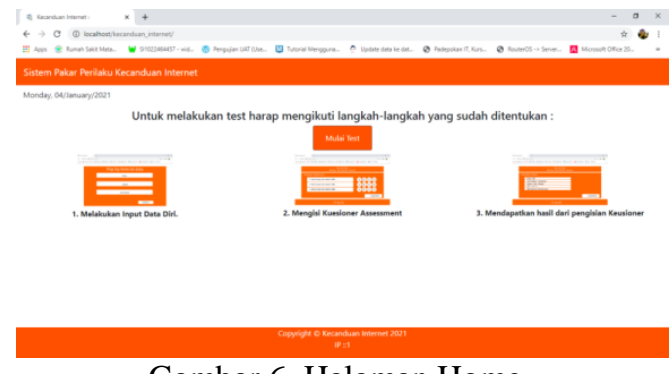

Gambar 6. Halaman Home.

Setelah User melakukan klik pada tombol Lanjutkan maka User/Penggunamasuk ke dalam alur untuk melakukan test, sehingga User/Pengguna tidak mengalami kebingungan bagaimana cara melakukan test.

\section{Halaman Pop Up Isi Data}

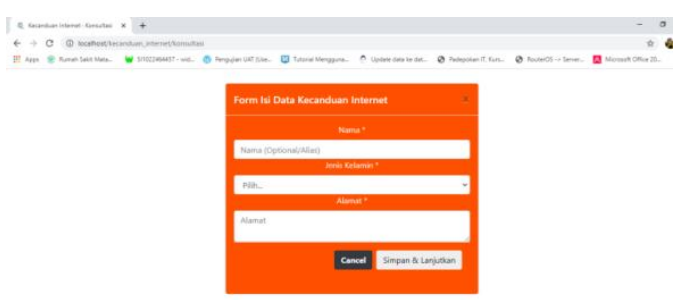

Gambar 7. Halaman Pop Up Isi Data

Pada halaman ini User/Pengguna diwajibkan untuk melakukan isi data diri sebelum melanjutkan ke halaman selanjutnya. Untuk kolom nama pengguna bisa di isi ataupun tidak diisi. User/Pengguna diwajibkan untuk melengkapi data diri berupa jenis kelamin dan alamat.semisal kolom Jenis Kelamin tidak diisi dan langsung menekan tombol 'Simpan \& Lanjutkan' maka Form tersebut tidak bisa lanjut dan akan keluar pesan Kolom ini wajib diisi. 


\section{Halaman Kuisioner}

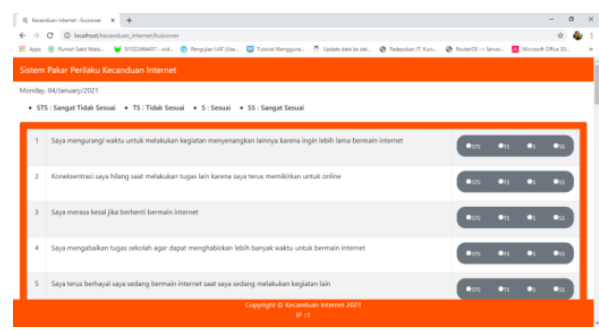

Gambar 8. Halaman Kuisioner

Pada halaman ini User diminta untuk mengisi kuesioner sejumlah 44 pertanyaan yang sesuai dengan karakter atau kepribadian dari User tersebut. Akan tetapi jika ada yang tidak sesuai dengan kepribadian User/Pengguna, tidak diisi juga tidak ada masalah. disediakan 4 variabel (jenis bobot) yang sudah ditentukan yaitu : STS : Sangat Tidak Sesuai, TS : Tidak Sesuai, S : Sesuai, dan SS : Sangat Sesuai.

\section{Halaman Hasil}

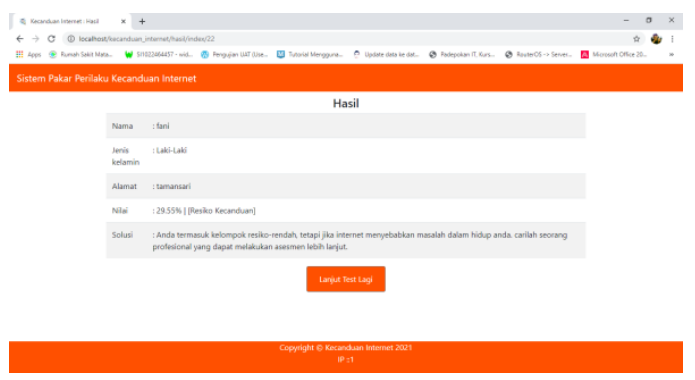

Gambar 9. Halaman Hasil

Pada Halaman tersebut User/Pengguna bisa mengetahui seberapa besar tingkat kecanduan terhadap perilakuKecanduan Internet. Dengan demikian User/Pengguna bisa melakukan konsultasi dengan pihak terkait untuk mendapatkan penanganan lebih lanjut.

\section{KESIMPULAN}

Dari penelitian yang sudah dilakukan dapat disimpulkan bahwa : Berdasarkan Survey yang telah dilakukan oleh APJII(Asosiasi Penyelenggara Jasa Internet Indonesia), koresponden/partisipan yang mendominasi Survey tersebut adalah Anak dengan rentan usia mulai 7 sampai 17 Tahun dan pada tahun 2018 didapatkan nilai 91\% pada usia tersebut sudah bisa menggunakan internet yang dilakukan di Indonesia dan semakin bertambah setiap tahunnya. Metode Forward Chaining dipilih dalam melakukan penelitian ini karena metode ini sesuai untuk studi kasus dengan variable 44 pertanyaan dan dapat Menentukan tingkat kecanduan yang sangat baik/tepat. Hasil dari Data Kuesioner yang sudah dibagikan kepada anak dengan usia antara 7 - 17 Tahun, ada 30\% yang sudah diuji dengan aplikasi ini, didapatkan hasil sebanyak $75 \%$ dengan hasil kecanduan dan harus diberikan tindakan khusus. Perancangan dan pembangunan sistem pengambil keputusan perilaku Kecanduan Internet dapat memberikan hasil diagnose berdasarkan fakta-fakta yang telah diberikan. Pemilihan menggunakan Metode Forward Chaining digunakan karena bisa mendapatkan hasil yang sangat baik/tepat. 
Procedia of Engineering and Life Science Vol. 1. No. 2 Juni 2021

Seminar Nasional \& Call Paper Fakultas Sains dan Teknologi (SENASAINS 2nd)

Universitas Muhammadiyah Sidoarjo

\section{REFERENSI}

[1] dr. Marianti. 03 Oktober 2017.https://www.alodokter.com/gangguan-kepribadian. Diakses pada 5 November 2019 eMarketer. Nov 2014.

[2] dr. Marianti. 03 Oktober 2017.https://www.alodokter.com/gangguan-kepribadian. Diakses pada 5 November 2019

[3] Asosiasi Penyelenggara Jasa Internet Indonesia (APJII). LAPORAN SURVEYPENETRASI \& PROFIL PERILAKU PENGGUNA INTERNET INDONESIA (2018) Ver. : S 20190518.

[4] https://tekno.kompas.com/read/2014/11/24/07430087/Pengguna.Internet.Indonesia.Nomor.Enam.Dunia. Diakses pada tanggal 15 Oktober 2019

[5] Kusrini. 2007. Konsep dan Aplikasi Sistem Pendukung Keputusan. Penerbit Andi, Yogyakarta

[6] Pahlevy, 2010.Pengertian Flowchart dan Definisi Data.http://www.landasanteori.com/2015/10/pengertianflowchart-dan definisi data.html.Diakses pada 6 November 2019.

[7] Brady, M., \& Loonam, J. 2010.Exploring the use of entity-relationship diagram as a technique to support grounded theory inquiry. Bradford: Penerbit Emerald Group. 